\title{
Effect of Low-Density Static Magnetic Field on the Oxidation of Ammonium by Nitrosomonas europaea and by Activated Sludge in Municipal Wastewater
}

\author{
Jasmina Filipič ${ }^{1,2}$, Barbara Kraigher², Brigita Tepuš ${ }^{1}$, Vanja Kokol ${ }^{3}$ and \\ Ines Mandić-Mulec ${ }^{1 *}$ \\ ${ }^{1}$ Ptuj Municipal Service Corporation, Puhova ulica 10, SI-2250 Ptuj, Slovenia \\ ${ }^{2}$ University of Ljubljana, Biotechnical Faculty, Department of Food Science and Technology, \\ Večna pot 111, SI-1000 Ljubljana, Slovenia \\ ${ }^{3}$ University of Maribor, Faculty of Mechanical Engineering, Institute for Engineering Materials and Design, \\ Smetanova ulica 17, SI-2000 Maribor, Slovenia \\ Received: March 2, 2014 \\ Accepted: February 23, 2015
}

\begin{abstract}
Summary
Ammonium removal is a key step in biological wastewater treatment and novel approaches that improve this process are in great demand. The aim of this study is to test the hypothesis that ammonium removal from wastewater can be stimulated by static magnetic fields. This was achieved by analysis of the effects of static magnetic field (SMF) on the growth and activity of Nitrosomonas europaea, a key ammonia-oxidising bacterium, where increased growth and increased ammonia oxidation rate were detected when bacteria were exposed to SMF at $17 \mathrm{mT}$. Additionally, the effect of SMF on mixed cultures of ammonia oxidisers in activated sludge, incubated in sequencing batch bioreactors simulating wastewater treatment process, was assessed. SMFs of 30 and $50 \mathrm{mT}$, but not of $10 \mathrm{mT}$, increased ammonium oxidation rate in municipal wastewater by up to $77 \%$ and stimulated ammonia oxidiser growth. The results demonstrate the potential for use of static magnetic fields in increasing ammonium removal rates in biological wastewater treatment plants.
\end{abstract}

Key words: biological wastewater treatment, static magnetic field, sequencing batch reactors, ammonia-oxidising bacteria, nitrification

\section{Introduction}

Rapid population growth increases problems associated with water pollution, especially in municipal areas (1). The influent to municipal wastewater treatment plants contains high levels of both organic and inorganic nitrogen and mineralisation of the former results in the release of ammonium (2). Ammonium is a common pollutant that is normally eliminated from wastewater by two processes, nitrification and denitrification (3). Nitrification is the biological oxidation of ammonia to nitrite, and subsequently to nitrate, by two groups of nitrifying bacteria. The first group, ammonia-oxidising bacteria (AOB), obtain energy for growth by oxidising ammonium to nitrite and are usually represented in wastewater treatment plants by two genera, Nitrosomonas and Nitrosospira (2). The second group, nitrite-oxidising bacteria (NOB)

\footnotetext{
*Corresponding author: Phone: +386 1320 3409; Fax: +386 1257 3390; E-mail: ines.mandic@bf.uni-lj.si
}

Abbreviations: $\mathrm{AOB}=$ ammonia-oxidising bacteria, $\mathrm{ATP}=$ adenosine triphosphate, $\mathrm{DO}=$ dissolved oxygen, MLSS=mixed liquor suspended solids, MPN=most probable number, $\mathrm{NOB}=$ nitrite-oxidising bacteria, $\mathrm{NH}_{4}^{+}-\mathrm{N}=$ ammonium nitrogen, $\mathrm{NO}_{2}^{-}-\mathrm{N}=$ nitrite nitrogen, $\mathrm{SBR}=\mathrm{se}-$ quencing batch reactor, $\mathrm{SMF}=$ static magnetic field, $\mathrm{TN}=$ total nitrogen, $\mathrm{TOC}=$ total organic carbon 
are represented by Nitrobacter and Nitrospira and oxidise nitrite to nitrate (4). Both groups typically grow autotrophically, obtaining carbon by fixation of $\mathrm{CO}_{2}$. Nitrosomonas europaea is a key AOB in the treatment of industrial and domestic wastewater; it plays an important role in the global nitrogen cycle (5-8) and has been used as a 'model' AOB for physiological and other studies (9).

Ammonia oxidation limits the rate of ammonium removal from wastewater and is one of the most sensitive biological processes during wastewater treatment. It is highly sensitive to various environmental stresses including changes in $\mathrm{pH}$, temperature and the presence of pollutants such as pharmaceuticals (10-12). AOB generally have low maximum specific growth rate, with doubling times in the range of 8 to $24 \mathrm{~h}$, and their high sensitivity to environmental stresses makes their activity a critical step in biological nitrogen removal (13). Novel approaches for optimising ammonium removal are therefore in great demand and increasing attention has been directed towards the potential for static magnetic fields (SMFs) to improve wastewater treatment (14).

Recent studies have demonstrated accelerated removal of organic substrates from artificial wastewater by static magnetic fields (SMF) (1,14-16). The maximum substrate removal (up to $44 \%$ ) from glucose-based artificial wastewater was observed at an SMF of $17.8 \mathrm{mT}$ (1). An SMF of 150-350 mT increased phenol degradation rate in bioreactors containing immobilised microbial beads (17) and formaldehyde degradation by activated sludge in artificial wastewater was increased by an SMF of $7 \mathrm{mT}$, decreasing formaldehyde concentration by up to $30 \%$ (16). Under anaerobic conditions, SMF increased ammonium oxidation by an anammox consortium (18). However, despite the importance of aerobic nitrification in activated sludge processes, the influence of SMF on aerobic ammonium-oxidising bacteria has not been investigated previously.

We have recently demonstrated that an SMF of $17 \mathrm{mT}$ inhibited the growth of two wastewater bacteria, Escherichia coli and Pseudomonas putida, and increased their dehydrogenase activity and intracellular adenosine triphosphate (ATP) levels (19). Here we test the hypothesis that SMF also influences ammonia oxidation by the model AOB $N$. europaea. In addition, we examine aerobic ammonium removal from municipal wastewater by sludge bacteria in sequencing batch reactors (SBRs) during exposure to four different SMFs $(0,10,30$ and $50 \mathrm{mT})$. Finally, we quantify the influence of SMF on the abundance of cultured N. europaea and sludge AOB in SBR.

\section{Materials and Methods}

\section{Magnetic field exposure}

An SMF was generated by a cylindrical coil as described previously (19). Activated sludge in SBR was exposed to the SMF in the centre of the coil, where the magnetic density $\left(B_{\mathrm{m}}\right)$ was maintained at $0,10,30$ or $50( \pm 0.5)$ $\mathrm{mT}$. N. europaea cultures were exposed to the SMF in Petri dishes (90-mm diameter) on a nonconductive stand at $B_{\mathrm{m}}$ of $(17 \pm 0.5) \mathrm{mT}$. The SMF was continuously monitored by FH51 Gauss meter (Magnet-Physics, Dr. Steingroever GmbH,
Köln, Germany). Exposed samples and unexposed controls were incubated in the dark at $(21 \pm 0.5){ }^{\circ} \mathrm{C}$, with temperature maintained by airflow (coil) or using a thermostatically controlled incubation chamber (coil and controls). All experiments with wastewater activated sludge and pure cultures were independently repeated three times. In addition, the experiments with pure cultures included triplicate cultures that were either exposed to the SMF (three biological replicates) or unexposed (three controls) within each independent experiment, giving nine exposed and nine unexposed experimental cultures for each experimental setup.

\section{Bacterial strains, media and growth conditions}

Frozen cultures of N. europaea Winogradsky (ATCC 19718, LGC Standards GmbH, Wesel, Germany) were inoculated into Erlenmeyer flasks containing $150 \mathrm{~mL}$ of sterile mineral salts medium for ammonia oxidisers containing $\left(\mathrm{NH}_{4}\right)_{2} \mathrm{SO}_{4} 0.5 \mathrm{~g} / \mathrm{L}(20)$. Cultures were incubated for four weeks at $28{ }^{\circ} \mathrm{C}$ and contamination was assessed periodically by inoculation of samples onto R2A agar plates (ATCC medium 1981, LGC Standards $\mathrm{GmbH}$ ).

\section{The influence of SMF on ammonium removal and bacterial abundance in batch cultures of $N$. europaea}

A culture of $N$. europaea $(15 \mathrm{~mL})$ was inoculated into $150 \mathrm{~mL}$ of fresh AOB medium (containing $\mathrm{NH}_{4}^{+} 150 \mathrm{mg} / \mathrm{L}$ ) and shaken at $200 \mathrm{rpm}$ for $30 \mathrm{~min}$ at $28^{\circ} \mathrm{C}$, after which 20 -mL samples were transferred to six Petri dishes. Three Petri dishes were exposed to the SMF for 7 days at $B_{\mathrm{m}}=(17 \pm 0.5) \mathrm{mT}$ and a temperature of $(21 \pm 0.5){ }^{\circ} \mathrm{C}$, and the three control Petri dishes were incubated under the same conditions, but not exposed to the SMF (only to the geomagnetic SMF). Ammonia oxidiser growth was monitored by determining the absorbance $\left(A_{650 \mathrm{~nm}}\right)$, ammonium and nitrite concentrations and viable cell concentration (most probable number, MPN). For MPN counts, serial dilutions were made in 96-well plates by transferring 40 $\mu \mathrm{L}$ of cell suspension to successive wells in microtiter plates containing $180 \mu \mathrm{L}$ of sterile ammonia oxidiser medium (20). Growth was assessed by the presence of nitrite with modified Griess-Ilosvay reagents after incubation at $28{ }^{\circ} \mathrm{C}$ for four weeks. MPN per mL of culture was estimated using the BAM-MPN Excel spreadsheet calculator (US FDA, Silver Spring, MD, USA).

\section{Sampling of activated sludge and wastewater}

Activated sludge and municipal wastewater were obtained from a municipal wastewater treatment plant (Ptuj Municipal Service Corporation, Slovenia) on February 9, 2012. Activated sludge was removed from $150 \mathrm{~L}$ of municipal wastewater by sedimentation, and wastewater without the active biomass was stored in 1.5-litre bottles at $-20{ }^{\circ} \mathrm{C}$ until use. Municipal wastewater at the time of sampling contained (in $\mathrm{mg} / \mathrm{L}$ ): $\mathrm{NH}_{4}{ }^{+}-\mathrm{N} 25.8, \mathrm{NO}_{3}^{-}-\mathrm{N} 0.13$, total nitrogen (TN) 26.8 and total organic carbon (TOC) 35.9. Nitrite was below the detection limit $(0.452 \mathrm{mg} / \mathrm{L})$. Fresh activated sludge was taken from the aeration basin of the Ptuj Municipal Service Corporation before each experiment and was added to previously stored wastewater after acclimatisation for four days. The final mixture used 
for all experiments contained $300 \mathrm{~mL}$ of fresh activated sludge (mixed liquor suspended solids (MLSS) $5.7 \mathrm{~g} / \mathrm{L}$ ) and $1700 \mathrm{~mL}$ of stored municipal wastewater.

\section{The influence of SMF on ammonium removal from wastewater in sequencing batch reactors}

The influence of SMF on ammonium removal was investigated in two sequencing batch reactors (SBR) with working volumes of $2 \mathrm{~L}$, one with magnetic field accessories (experimental samples) and the other without magnetic modification (control samples). The SBRs were inoculated with $300 \mathrm{~mL}$ of fresh activated sludge (MLSS, 5.7 $\mathrm{g} / \mathrm{L})$ and were exposed to SMF of 10,30 or $50( \pm 0.5) \mathrm{mT}$ or unexposed (control bioreactor) for four days at (21 \pm 0.5$)$ ${ }^{\circ} \mathrm{C}$. During this acclimatisation period, which allowed adaptation of microorganisms in activated sludge to the new conditions, $\mathrm{pH}$ was maintained at $7.8 \pm 0.2$ and dissolved oxygen (DO) at $(3.0 \pm 0.3) \mathrm{mg} / \mathrm{L}$. Acclimatised sludge was then mixed with $1700 \mathrm{~mL}$ of stored municipal wastewater, and the system continued to be operated at the same conditions: $0,10,30$ or $50 \mathrm{mT}$, temperature of $(21 \pm 0.5){ }^{\circ} \mathrm{C}$, and sampled hourly for $25 \mathrm{~h}$ to analyse ammonium and nitrate concentrations and ammonia oxidiser MPN. The experiment was repeated independently three times.

The ammonium oxidation rate $\left(q_{\mathrm{N}}\right)$ was expressed in mg of $\mathrm{NH}_{4}^{+}-\mathrm{N}$ removed per $\mathrm{h}$ per $\mathrm{g}$ of MLSS, calculated as follows:

$$
q_{\mathrm{N}}=\frac{\mathrm{d} \gamma_{\mathrm{NH}_{4}^{+}-\mathrm{N}}}{\mathrm{d} t \gamma_{\mathrm{X}}}
$$

where $\mathrm{d} \gamma$ is the concentration of $\mathrm{NH}_{4}{ }^{+} \mathrm{N}$ (in $\mathrm{mg} / \mathrm{L}$ ) utilised in time interval $\mathrm{d} t(\mathrm{~h})$ and $\gamma_{\mathrm{x}}$ is the concentration of the activated sludge (in g/L), i.e. MLSS (21).

\section{Chemical analyses}

Ammonium $\left(\mathrm{NH}_{4}{ }^{+} \mathrm{N}\right)$, nitrate $\left(\mathrm{NO}_{3}{ }^{-} \mathrm{N}\right)$, nitrite $\left(\mathrm{NO}_{2}{ }^{-}\right.$ $-\mathrm{N}$ ) and total nitrogen (TN) concentrations were measured according to standard methods: SIST ISO 7150$-1: 1996$ (22) for $\mathrm{NH}_{4}{ }^{+}-\mathrm{N}$, ISO 10304-1:2007 (23) for $\mathrm{NO}_{3}^{-}-\mathrm{N}$ and $\mathrm{NO}_{2}^{-}-\mathrm{N}$ using the ion chromatograph DX-100, (Sanivalle, CA, USA) and SIST EN 12260:2003 (24) for TN, following oxidation of nitrogen oxides, using the TOC analyser equipped with a TN measuring unit TOC-VCPN (Shimadzu, Kyoto, Japan). MLSS were measured according to standard methods (APHA method 2540 D) (25). The $\mathrm{pH}$ and DO concentration were measured using a digital, portable $\mathrm{pH}$ and $\mathrm{DO}$ meter (HQ 40d multimeter, Hach-Lange, Loveland, CO, USA), respectively.

\section{Statistical analysis}

Data analysis and graphical representation were performed using Excel (Microsoft, Redmond, WA, USA). Comparisons between treatments were performed using a two-sample Student's t-test assuming equal variance (differences were considered significant at $\mathrm{p}<0.05)$. Values are reported as mean \pm standard error of nine independent replicates for experiments with $N$. europaea and for nine independent replicates for experiments in the SBR bioreactors.

\section{Results and Discussion}

\section{The influence of SMF on ammonia oxidation and growth of N. europaea}

Removal of ammonium nitrogen in wastewater treatment plants is limited by the rate of ammonia oxidation by AOB. This work shows for the first time that SMF, at 17 $\mathrm{mT}$, significantly stimulated the removal of ammonia by the model chemolitotrophic wastewater AOB N. europaea. Cultures of N. europaea were exposed to an SMF of $17 \mathrm{mT}$, which had previously been found to influence growth and physiology of E. coli and P. putida (19). Ammonium and nitrite concentrations initially decreased and increased, respectively, in a similar manner in both exposed and unexposed samples and no influence of SMF was observed (Fig. 1). This initial increase in nitrification was presumably due to the transfer of N. europaea cultures into the fresh medium where ammonium and oxygen were abundant. Ammonium and nitrite did not change significantly in exposed or unexposed cultures during the first five days. After this transient lag phase, ammonium oxidation resumed with a marked difference between the exposed and unexposed cultures, such that SMF exposure for 7 days resulted in $(30 \pm 4) \%(p=0.037)$ increase in ammonium removal and a corresponding $(26 \pm 5) \%(p=0.042)$ increase in nitrite concentration, in comparison with unexposed controls (Fig. 1). Dehydrogenase activity in Escherichia coli and Pseudomonas putida was also stimulated by SMF at $17 \mathrm{mT}$, but stimulation increased within $2 \mathrm{~h}$ of exposure and a prolonged lag phase was not detected (19). A rapid depletion of oxygen might have caused the lag phase observed in the experiments with N. europaea, as nitrification is sensitive to oxygen fluctuations (26).

SMF of $17 \mathrm{mT}$ also stimulated growth of N. europaea, which was, like stimulation of ammonium oxidation, detected only after five days of incubation. The ratio of $N$. europaea MPN counts in exposed and unexposed cultures was not significantly different on days $1(\mathrm{p}=0.071)$ or 3 $(\mathrm{p}=0.060)$, but increased to $1.4\left(\mathrm{p}=5.4 \cdot 10^{-10}\right)$ on day 5 and to

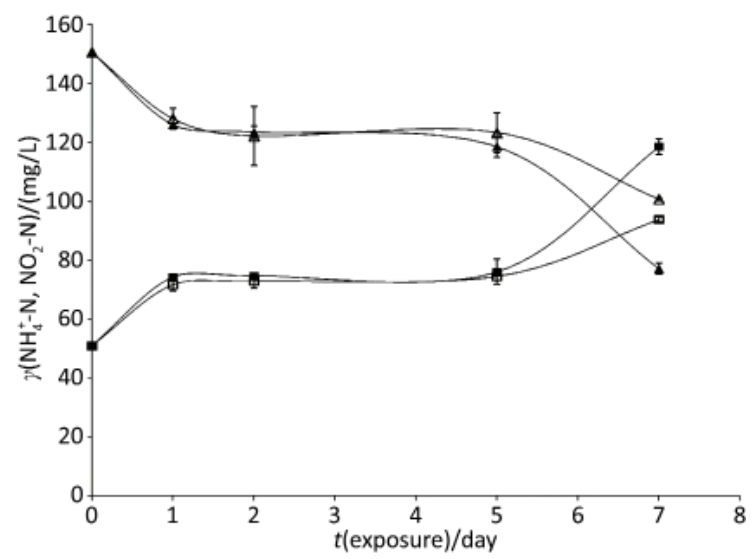

Fig. 1. The effect of static magnetic field (SMF) of $17 \mathrm{mT}$ on the oxidation of ammonia to nitrite by Nitrosomonas europaea. Cultures were exposed to SMF for 7 days. The error bars represent standard error of the mean $(N=9)$. $\Delta$ and $\Delta$ : concentrations of $\mathrm{NH}_{4}{ }^{+} \mathrm{N}(\mathrm{mg} / \mathrm{L})$ in exposed and unexposed cultures, respectively; and $\square$ : concentrations of $\mathrm{NO}_{2}-\mathrm{N}(\mathrm{mg} / \mathrm{L})$ in exposed and unexposed cultures, respectively 
$1.51\left(\mathrm{p}=2.3 \cdot 10^{-8}\right)$ on day 7 (Fig. 2), when stimulation of ammonium oxidation was also observed. It is possible that only actively growing cells are sensitive to magnetic field, consistently with our previous work (19) showing that the effect of magnetic field on heterotrophic bacteria is most prominent in conditions supporting the highest growth rates. Although SMF stimulated the growth of $N$. europaea, in contrast to the inhibition of growth of E. coli and P. putida (19), in both experiments cultures were exposed to the same SMF density. The different responses, inhibition vs. stimulation, may be due to the different metabolic and energy-generating pathways of heterotrophs and a chemolithotroph and the much slower growth of N. europaea.

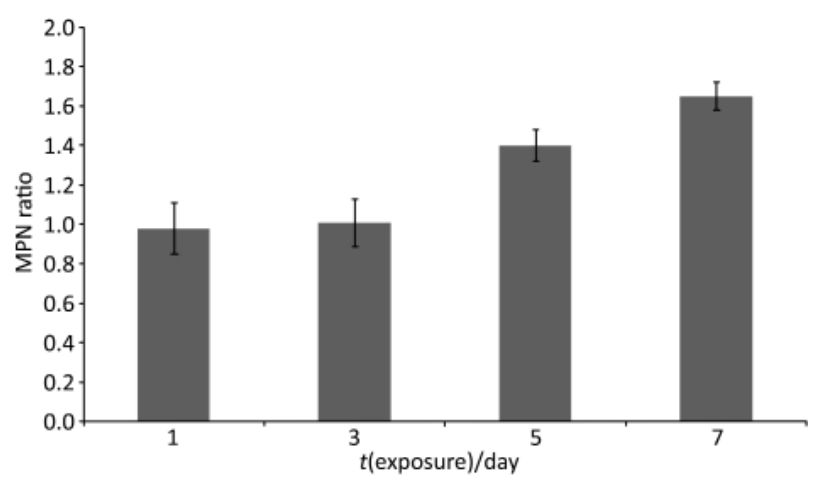

Fig. 2. The effect of static magnetic field (SMF) of $17 \mathrm{mT}$ on the ratio of viable cell concentration (most probable number, MPN) of Nitrosomonas europaea in exposed and unexposed cultures. The error bars represent standard error of the mean $(N=9)$. After five and seven days of exposure to the SMF, MPN ratio was significantly higher than $1(\mathrm{p}<0.05)$, indicating a positive influence of the SMF

\section{The influence of SMF on ammonium removal from municipal wastewater and on abundance of $A O B$ in activated sludge}

Stimulation of $N$. europaea growth and nitrification activity in cultures by SMF suggested the potential for stimulation of nitrification in wastewater treatment processes, which was tested using municipal wastewater and wastewater sludge bacteria. The influence of four different SMF densities $(B=0,10,30$ or $50 \mathrm{mT})$ on the removal of $\mathrm{NH}_{4}{ }^{+} \mathrm{N}$ from municipal wastewater was studied in SBRs at constant temperature of $(21 \pm 0.5){ }^{\circ} \mathrm{C}$. The results presented in Fig. 3 and Table 1 indicate an initial lag phase with very low ammonium oxidation rates for approx. $2 \mathrm{~h}$ in both exposed and unexposed cultures. Ammonia oxidation then increased in all treatments but at significantly higher rates in SBRs exposed to 50 or $30 \mathrm{mT}$ than in control bioreactors (Table 1). The strongest increase of $(43 \pm 2)$ $\%$ at $2-8 \mathrm{~h}$ and $(77 \pm 5) \%$ at $8-12 \mathrm{~h}$ was detected in SBRs exposed to $50 \mathrm{mT}$, compared to the unexposed SBRs. In contrast, exposure to $10 \mathrm{mT}$ reduced the ammonium removal rate to $(0.12 \pm 0.03) \mathrm{mg}$ of $\mathrm{NH}_{4}{ }^{+} \mathrm{N}$ per $\mathrm{g}$ of MLSS per hour, which was $(40 \pm 3) \%$ lower than the control rate after exposure for $12-25 \mathrm{~h}$ (Table 1 ). SMF therefore had positive or negative effects on ammonium removal rates from wastewater in SBRs, depending on the density of the applied magnetic field. A positive and negative response to

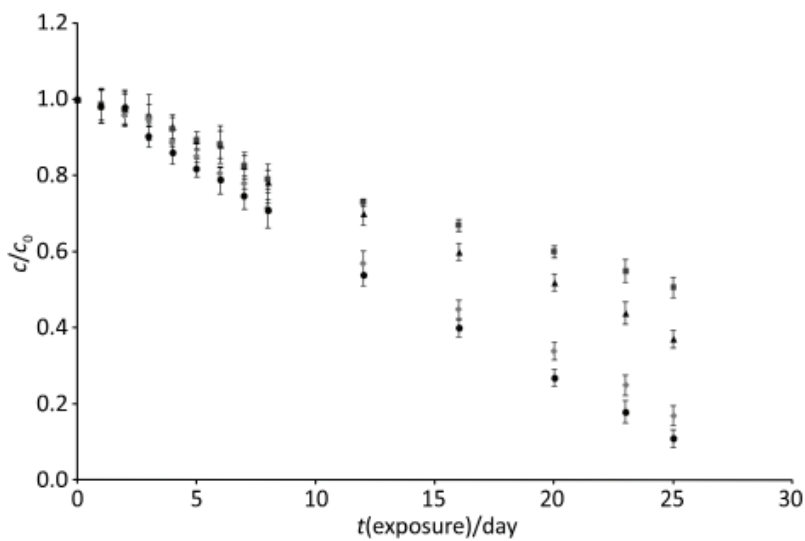

Fig. 3. The effect of static magnetic field $(0,10,30$ or $50 \mathrm{mT})$ on ammonium removal from wastewater by activated sludge during exposure for $25 \mathrm{~h}$ at $21^{\circ} \mathrm{C}$, plotted as the ratio of ammonium concentration after the period $(t)$ of exposure $(c)$ to the initial concentration $\left(c_{0}\right)$. The error bars represent standard error of the mean $(N=3)$. Sequencing batch reactors were exposed to 0 $(\bullet), 10(\square), 30(\diamond)$ and $50 \mathrm{mT}(\bullet)$

Table 1. The influence of static magnetic field (SMF) on ammonium removal from wastewater in sequencing batch reactors (SBR) by activated sludge

\begin{tabular}{ccccc}
\hline \multicolumn{5}{c}{ Ammonium oxidation rate } \\
\cline { 2 - 5 } mg of $\mathrm{NH}_{4}{ }^{+}$-N per g of MLSS per h \\
\cline { 2 - 5 }$B / \mathrm{mT}$ & \multicolumn{4}{c}{$t / \mathrm{h}$} \\
\cline { 2 - 5 } & $0-2$ & $2-8$ & $8-12$ & $12-25$ \\
\hline 0 & $0.060 \pm 0.007$ & $0.32 \pm 0.04$ & $0.24 \pm 0.03$ & $0.20 \pm 0.02$ \\
10 & $0.060 \pm 0.007$ & $(0.30 \pm 0.03)^{*}$ & $(0.20 \pm 0.02)^{*}$ & $(0.12 \pm 0.03)^{*}$ \\
30 & $0.060 \pm 0.007$ & $(0.44 \pm 0.03)^{*}$ & $(0.39 \pm 0.03)^{*}$ & $(0.26 \pm 0.02)^{*}$ \\
50 & $0.060 \pm 0.007$ & $(0.46 \pm 0.02)^{*}$ & $(0.42 \pm 0.02)^{*}$ & $(0.31 \pm 0.02)^{*}$ \\
\hline
\end{tabular}

SBRs were exposed to SMF $(0,10,30$ and $50 \mathrm{mT})$ for $25 \mathrm{~h}$ at $21^{\circ} \mathrm{C}$. Values represent average ammonium oxidation rates at indicated time intervals during the exposure to SMF.

*significant difference $(p<0.05)$ compared to unexposed controls at $0 \mathrm{mT}$, showing the influence of the SMF

MLSS=mixed liquor suspended solids, $B=$ magnetic field density

SMF of different strengths has also been observed in other processes. For example, anammox process was stimulated at the SMF of $30 \mathrm{mT}$ but inhibition of this process occurred at $110 \mathrm{mT}$ (18). The influence of SMF therefore depends on the strength of the applied SMF but the specific response to a particular SMF density depends also on the process that is studied.

This work also provides the first evidence that SMF increases the growth of sludge AOB. The abundance of AOB in wastewater SBRs exposed to different SMF densities $(0,10,30$ and $50 \mathrm{mT})$ was determined by MPN after exposure for $25 \mathrm{~h}$ following the four-day acclimatisation phase of the activated sludge. AOB abundance increased significantly at $50 \mathrm{mT}\left(1.4\right.$-fold; $\left.\mathrm{p}=2.8 \cdot 10^{-13}\right)$ and at $30 \mathrm{mT}$ (1.2-fold; $\left.\mathrm{p}=1.2 \cdot 10^{-8}\right)$, but not at $10 \mathrm{mT}(\mathrm{p}=0.1)$, when compared to the unexposed samples (Fig. 4). An increase in $\mathrm{AOB}$ abundance may in part be responsible for higher removal rates measured in SBRs exposed to 30 or $50 \mathrm{mT}$ but 


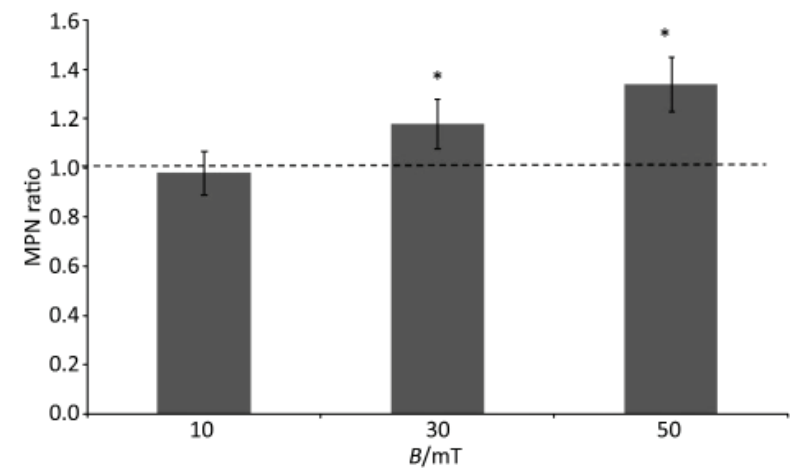

Fig. 4. The effect of static magnetic field (SMF) of 10, 30 and $50 \mathrm{mT}$ on the ratio of viable cell concentration (determined by most probable number, MPN) of ammonia-oxidising bacteria (AOB) in activated sludge. The error bars represent standard error of the mean $(N=3)$. Dashed line (no influence of SMF) indicates a ratio of one. Values that are above the dashed line indicate a positive influence of the SMF. ${ }^{*}$ indicates a ratio significantly different from $1(\mathrm{p}<0.05)$

other mechanisms should be taken into consideration, especially as a change in the activity but not in the abundance was observed at $10 \mathrm{mT}$ exposure.

Several mechanisms influencing the growth and/or enzyme activities may be responsible for the observed effects. One of the most intensely studied enzymes in relation to the effects of magnetic field is B12-dependent ethanol ammonia lyase for which a decrease in $v_{\max } / K_{\mathrm{m}}$ at $100-\mathrm{mT}$ magnetic field density was reported (27). It is known that enzymatic reactions that are responsive to magnetic fields must generate paramagnetic particles or spin correlated radicals (28-30). Interestingly, the hydroxylamine oxidase-associated tetraheme cyt cm552 from $N$. europaea, which catalyses the oxidation of hydroxylamine to nitrite, was reported to carry paramagnetic heme species (31). However, many enzymes with radical intermediates will not produce magnetic field-dependent reaction kinetics and further studies are needed to test this hypothesis. Another possibility is changes in transcriptional activity of genes involved in ammonia oxidation, as SMF has been shown to influence transcriptional activity of various genes $(32,33)$. Although the mechanisms behind the observed phenomena are not understood and require further study, the work clearly shows that SMF stimulates ammonium removal by mixed activated sludge bacteria and by the pure culture of an important wastewater nitrifier.

\section{Conclusions}

This work shows for the first time that SMF positively influenced ammonia oxidation and the growth of an important and very sensitive wastewater AOB, Nitrosomonas europaea in the laboratory pure culture. Results showed that SMF of $17 \mathrm{mT}$ increased ammonium removal for $(30 \pm 4) \%$ and nitrite removal for $(26 \pm 5) \%$ and also stimulated growth of $N$. europaea. Additionally, in the experiments with activated sludge and municipal wastewater, we showed that SMF of $50 \mathrm{mT}$ increased ammonium removal rates by activated sludge bacteria in SBRs by up to $77 \%$ and increased the abundance of sludge AOB. In con- trast, SMF of $10 \mathrm{mT}$ decreased the activity by up to $40 \%$ but did not influence the growth of bacteria in SBRs. These findings may have important implications in the field of biological wastewater treatment and suggest potential strategies for the removal of mineral nitrogen and growth manipulation of key nitrifiers in municipal wastewater treatment plants.

\section{Acknowledgements}

This work was financed by the European Union, European Social Fund and by the ARRS program grant JP4116. We would like to thank Dr. Tjaša Danevčič for her help with the experiments and for useful discussions, and we thank P.H. van Loosdrecht for critical reading of the manuscript and constructive suggestions.

\section{References}

1. Yavuz H, Celebi SS. Effects of magnetic field on activity of activated sludge in wastewater treatment. Enzyme Microb Tech. 2000;26:22-7.

http://dx.doi.org/10.1016/S0141-0229(99)00121-0

2. Gerardi MH. Wastewater bacteria. New Jersey, NY, USA: John Wiley \& Sons; 2006.

3. Graaf AA, Bruijn P, Robertson LA, Jetten MSM, Kuenen JG. Autotrophic growth of anaerobic ammonium-oxidizing microorganisms in a fluidized bed reactor. Microbiology. 1996; 142:2187-96.

http://dx.doi.org/10.1099/13500872-142-8-2187

4. Daims H, Nielsen JL, Nielsen PH, Schleifer KH, Wagner M. In situ characterization of Nitrospira-like nitrite-oxidizing bacteria active in wastewater treatment plants. Appl Environ Microb. 2001;67:5273-84.

http://dx.doi.org/10.1128/AEM.67.11.5273-5284.2001

5. Henze M. Theories for estimation of the fraction of denitrifiers in combined nitrifying-denitrifying treatment plants. Water Res. 1987;21:1521-4. http://dx.doi.org/10.1016/0043-1354(87)90136-9

6. Siegrist $H$. Nitrogen removal from digester supernatant comparison of chemical and biological methods. Water Sci Technol. 1996;34:399-406. http://dx.doi.org/10.1016/0273-1223(96)00529-X

7. Bagnall JP, Ito A, McAdam EJ, Soares A, Lester JN, Cartmell E. Resource dependent biodegradation of estrogens and the role of ammonia oxidising and heterotrophic bacteria. J Hazard Mater. 2012;239-240:56-63. http://dx.doi.org/10.1016/j.jhazmat.2012.06.012

8. Lipus LC, Acko B, Hamler A. Magnetic device simulation modelling and optimisation for scale control. Int J Simul Model. 2012;11:141-9.

http://dx.doi.org/10.2507/IJSIMM11(3)3.205

9. Arp DJ, Sayavedra-Soto LA, Hommes NG. Molecular biology and biochemistry of ammonia oxidation by Nitrosomonas europaea. Arch Microbiol. 2002;178:250-5. http://dx.doi.org/10.1007/s00203-002-0452-0

10. Guo J, Peng Y, Huang H, Wang S, Ge S, Zhang J, Wang Z. Short- and long-term effects of temperature on partial nitrification in a sequencing batch reactor treating domestic wastewater. J Hazard Mater. 2010;179:471-9. http://dx.doi.org/10.1016/j.jhazmat.2010.03.027

11. Kraigher B, Mandic-Mulec I. Nitrification activity and community structure of nitrite-oxidizing bacteria in the bioreactors operated with addition of pharmaceuticals. J Hazard Mater. 2011;188:78-84.

http://dx.doi.org/10.1016/j.watres.2008.08.006 
12. Wang S, Gunsch CK. Effects of selected pharmaceutically active compounds on the ammonia oxidizing bacterium Nitrosomonas europaea. Chemosphere. 2011;82:565-72. http://dx.doi.org/10.1016/j.chemosphere.2010.10.007

13. Watson SW, Valois FW, Waterbury JB. The family Nitrobacteraceae. In: Starr MP, Stolp J, Trüper HG, Balows A, Schlegel HG, editors. The prokaryotes: a handbook on habitats, isolation, and identification of bacteria. New York, NY, USA: Springer-Verlag; 1981. pp. 1005-22. http://dx.doi.org/10.1007/978-3-662-13187-9_80

14. Tomska A, Rajczyk MJ. The effect of magnetic field on wastewater treatment with activated sludge method. Environ Prot Eng. 2004;30:156-60.

15. Ji Y, Wang Y, Sun J, Yan T, Li J, Zhao T, et al. Enhancement of biological treatment of wastewater by magnetic field. Bioresour Technol. 2010;101:8535-40. http://dx.doi.org/10.1016/j.biortech.2010.05.094

16. Łebkowska M, Rutkowska NA, Pajor E, Pochanke Z. Effect of static magnetic field on formaldehyde biodegradation in wastewater by activated sludge. Bioresour Technol. 2011;102: 8777-82. http://dx.doi.org/10.1016/j.biortech.2011.07.040

17. Jung J, Sofer S. Enhancement of phenol biodegradation by south magnetic field exposure. J Chem Technol Biotechnol. 1997;70:299-303. http://dx.doi.org/10.1002/(SICI)1097-4660(199711)70:3

18. Liu S, Yang F, Meng F, Chen H, Gong Z. Enhanced anammox consortium activity for nitrogen removal: impacts of static magnetic field. J Biotechnol. 2008;138:96-102. http://dx.doi.org/10.1016/j.jbiotec.2008.08.002

19. Filipič J, Kraigher B, Tepuš B, Kokol V, Mandic-Mulec I. Effects of low-density static magnetic fields on the growth and activities of wastewater bacteria Escherichia coli and Pseudomonas putida. Bioresour Technol. 2012;120:225-32. http://dx.doi.org/10.1016/j.biortech.2012.06.023

20. Schmidt EL, Belser LM. Autotrophic nitrifying bacteria. Methods of soil analyses, Part 2 - Microbiological and biochemical properties. SSSA Book Series 5; 1994. pp. 159-78.

21. Tchobanoglous G, Burton FL, Stensel DH. Wastewater engineering: treatment and reuse. Boston, MA, USA: Metcalf \& Eddy Inc, McGraw-Hill; 1998.

22. SIST ISO 7150-1:1996. Water quality - Determination of ammonium - Part 1: Manual spectrometric method. Slovenian Institute for Standardization, Ljubljana, Slovenia; 1996 (in Slovenian).
23. ISO 10304-1:2007. Water quality - Determination of dissolved anions by liquid chromatography of ions - Part 1: Determination of bromide, chloride, fluoride, nitrate, nitrite, phosphate and sulfate. Geneva, Switzerland: International Organization for Standardization; 2007.

24. SIST EN 12260:2003. Water quality - Determination of nitrogen - Determination of bound nitrogen $(\mathrm{TNb})$, following oxidation to nitrogen oxides. Slovenian Institute for Standardization, Ljubljana, Slovenia; 2003.

25. APHA 1998. Method 2540 D. Total suspended solids dried at 103-105 ${ }^{\circ} \mathrm{C}$. Standard methods for the examination of water and wastewater. Washington DC, USA: American Public Health Association;1998. pp. 2-56.

26. Yu R, Chandran K. Strategies of Nitrosomonas europaea 19718 to counter low dissolved oxygen and high nitrite concentrations. BMC Microbiol. 2010;10:70. http://dx.doi.org/10.1186/1471-2180-10-70

27. Harkins TT, Grissom CB. Magnetic field effects on B12 ethanolamine ammonia lyase: evidence for a radical mechanism. Science. 1994;263:958-60. http://dx.doi.org/10.1126/science.8310292

28. Grissom CB. Magnetic field effects in biology: a survey of possible mechanisms with emphasis on radical-pair recombination. Chem Rev. 1995;95:3-24. http://dx.doi.org/10.1021/cr00033a001

29. Hore PJ. Are biochemical reactions affected by weak magnetic fields? Proc Natl Acad Sci USA. 2012;109:1357-8. http://dx.doi.org/10.1073/pnas.1120531109

30. Steiner UE, Ulrich T. Magnetic field effects in chemical kinetics and related phenomena. Chem Rev. 1989;89:51-4. http://dx.doi.org/10.1021/cr00091a003

31. Kim HJ, Zatsman A, Upadhyay AK, Whittaker M, Bergmann D, Hendrich MP, Hooper AP. Membrane tetraheme cytochrome $\mathrm{cm}_{552}$ of the ammonia-oxidizing Nitrosomonas europaea: a ubiquinone reductase. Biochemistry. 2008;47:6539-51. http://dx.doi.org/10.1021/bi8001264

32. Gao W, Liu Y, Zhou J, Hongjun P. Effects of a strong static magnetic field on bacterium Shewanella oneidensis: an assessment by using whole genome microarray. Bioelectromagnetics. 2005;26:558-63. http://dx.doi.org/10.1002/bem.20133

33. Snoussi S, May AE, Coquet L, Chan P, Jouenne T, Landoulsi A, Dé E. Adaptation of Salmonella enterica Hadar under static magnetic field: effects on outer membrane protein pattern. Proteome Sci. 2012;10:6. http://dx.doi.org/10.1186/1477-5956-10-6 